\title{
Feasibility the Using of Coffee Waste for Bali Cattle Fattening in Bangli
}

\author{
Parwati IA, Suyasa N \\ Bali Assessment Institute for Agricultural Technology \\ Jl. By Pass Ngurah Rai, Denpasar 80222, Bali, Indonesia \\ dayuparwati@yahoo.com
}

\begin{abstract}
In Bali, one of the important issues related to livestock development is the issue of feed. The farmers often complain because of high prices of feed that often do not correspond to price of product increase. One of the alternatives for the provision of feed that are cheap and competitive is through the utilization of plantation waste. To view the financial feasibility of livestock farmers is introducting of coffee waste research in the Belantih Village, District of Kintamani, Bangli Regency. The eligible criteria used is Net Present Value (NPV), B/C ratio and the Internal Rate of Return (IRR), followed by the sensitivity test. From the analysis it was founded that the addition of coffee bran into the feed (forage + biocas) of fattening cattle to include net income (year 0 up to $10^{\text {th }}$ ) against level discount factor (df) $12 \%$ obtained NPV of Rp. 15,079,587.91; IRR of $21 \%$ and $\mathrm{B} / \mathrm{C}$ ratio of 2.62. In farm of fattening who were given forage just acquired a negative NPV of Rp. $14,547,191.50 ; 1 \%$ IRR and B/C ratio of 1.04 . From the economic analysis, it was concluded that the using coffee bran is feasible to be introduced due to $\mathrm{B} / \mathrm{C}>1$ compared to the usual management by the farmers. The sensitivity test showed that the beef cattle fattening are very sensitive to changes.
\end{abstract}

Key Words: Feasibility Effort, Waste Coffee, Fattening, Bali Cattle

\section{INTRODUCTION}

The potential development of beef cattle for the Province of Bali is very good, because it is supported by the potential market. Besides the opportunity for business development is supported by the raising of beef prices in Bali that occurred at the last 10 years, the beef price raising is about 5.26 to $23.8 \%$ per year consistenly.

In Bali, one of the important issues related to livestock development is the issue of feed. The farmers often complain because of high feed prices that often do not correspond to the price development of the product (Bali Provincial Livestock Office 2009). On the other hand for the availability of forage, Bali has limited of land as constraints and the development of industry and services that to be competitive of land use (Tisna 2002). Therefore, one of the alternatives for the provision of feed that are cheap and competitive is using agricultural waste, livestock waste and agro industrial waste (Parwati et al. 2009). According to Suyasa et al. (2004) in Bali there are several types of waste production which is large enough such rice straw that now already widely used as a feed source. Other types of waste from plantation is the coffee waste that can be processed so that it becomes raw material to be used as concentrate Guntoro et al. (2004) supported by Budiari \& Parwati (2010). Coffee pulp production is about $48 \%$, consits of $42 \%$ of the fruit peel and $6 \%$ of coffee seed bran (Zainudin et al. 1995). Based on the results of proximate analysis, fermented of coffee waste by Aspergillus niger can improve of protein and decrease of crude fiber. The results of the assessment conducted by Parwati et al. (2009), fermenting waste coffee pulp with $A$. niger can replace the rice bran that had been introduced by livestock farmers in Kintamani as a concentrate feed for cattle, because the expensive of rice bran (that is Rp. 1,500-2,000/kg). In addition, the utilization of the coffee waste as feed for cattle could increase the value-added of livestock in plantation area because of 
increasing coffee pulp used. A benefit of keeping a cattle in a plantation area is the cattle can supply an organic fertilizer for plants (Guntoro et al. 2004). Although the production of coffee waste is large, but their nutrient is poor because they have low protein content and high crude fiber (Zaenuddin et al. 1995). Waste coffee also contains tannins which can interfere with digestion when given at high doses. In the other side, plantation crops generally harvested only once a year (except cocoa can be harvested three times per year), so the production is seasonal. When given in the fresh form will get problems in ensuring supply.

Through the process of fermentation with A. niger, crude protein value of coffee skin can be improved and the content of substances inhibiting digestion can be pressed. The purpose of this study was to determine the level of profitability and financial feasibility (BCR, NPV, and IRR) obtained by using of technologies introduced in cattle fattening farm.

\section{MATERIAL AND METHODS}

The study was conducted in the Village Belantih, District Kintamani, Bangli Regency. The selection of farmers respondent was conducted by random sampling, the number of responden was 20 of beef cattle farmers that using a coffee waste as a feed for beef cattle fattening and 20 of beef cattle farmers who give forage roughage as a feed, so that the total number of farmers respondent were 40. The data was collected through interviewing, recording and observation. The data collected was analyzed with the eligibility criteria and benefits according to Gittinger (1986).

\section{$\mathrm{B} / \mathrm{C}$ ratio}

$\mathrm{B} / \mathrm{C}$ ratio is the ratio between benefit and costs can be written with the formula

$$
\begin{aligned}
& \mathrm{B} / \mathrm{C}=\left\{\sum_{\mathrm{t}=1}^{\mathrm{n}} \mathrm{B}_{\mathrm{t}} /(1+\mathrm{i})^{\mathrm{t}}\right\} /\left\{\sum_{\mathrm{t}=1}^{\mathrm{n}} \mathrm{C}_{\mathrm{t}} /(1+\mathrm{i})^{\mathrm{t}}\right\} \\
& i=\operatorname{rSate}(\%)
\end{aligned}
$$

If $\mathrm{B} / \mathrm{C}>1$, then the project can be said to be feasible. Whereas if the $\mathrm{B} / \mathrm{C}<1$, then the project is not feasible, because it will suffer losses.

\section{Net present value}

Net present value (NPV) of the flow of benefits and costs is the difference between the net value of the current net value of the benefit and cost flows. Difference in cash inflow with a cash outflow that occurred every year called the Net benefit. Net benefit that occur each year discounted with the opportunity cost of capital generally accepted using the net present value of each benefit that occur per year. Total net present value of these benefits will generate NPV is mathematically written by the formula:

$$
N P V=\sum_{t=1}^{n} \frac{B_{t}-C_{t}}{(1+i)^{t}}
$$

$B_{t}$ : A benefit reception every year; $C_{t}$ : The costs incurred every year; $n$ : The economic life of the project; i: The discount rate applicable 
If the NPV $>0$ (positive), the project can be declared eligible to be carried out or accepted as it is profitable. Whereas if $\mathrm{NPV}<0$ (negative), the project is not feasible, and when NPV $=0$, means additional project benefits equal to the additional costs incurred.

\section{Internal rate of return}

If the internal rate of return (IRR) of a project is equal to the interest rate applicable currency as the social discount rate, the NPV of the project is equal to zero. Discount level thus called IRR. The level is the maximum interest rate that can be paid by the project's resources are used for projects requiring more funds for operating expenses and investments and new projects to a level of capital return. This is a rate of return on capital that is not yet finished each period while the capital will be invested in the project (Gittinger 1986). For an explanation by interpolation, by calculating the discount rate based on the calculation of the new interest rate ( $i_{1}$ and $i_{2}$ ) or summarized by:

$$
\operatorname{IRR}=i_{1}+\left(i_{2}-i_{1}\right) \frac{N P V_{1}}{N P V_{1}-N P V_{2}}
$$

If the IRR of a project is equal to the interest rate applicable currency as the social discount rate, the NPV of the project is equal to zero. And, if the IRR of a project smaller than the prevailing interest rate $(\mathrm{IRR}<\mathrm{i})$, means the NPV is smaller than zero $(\mathrm{NPV}<0)$. But if its IRR is greater than or equal to the prevailing interest rate (IRR> i), meaning its NPV is greater than or equal to zero $(N P V>0)$. In the state of IRR $>i$ or $N P V>0$, can be interpreted that the project is feasible. Meanwhile, if the IRR $<\mathrm{i}$ or $\mathrm{NPV}<0$, then the project is not feasible, because the rate of return lower than the prevailing lending rates. Then performed a sensitivity analysis (the treatment of the lack of provisions for) to face the uncertainty that can only occur in any circumstances that have been predicted or estimated. Sensitivity analysis performed on the increase and decrease in input prices financially.

\section{RESULTS AND DISCUSSION}

Financial feasibility analysis was done to look at the feasibility of using waste coffee in fattening of beef cattle. An analysis of the feasibility its output indicator is the sale of livestock and waste while the input indicators is the purchase of seeds, the manufacture of cages, depreciation cage, purchase of forage, purchasing concentrates (bran coffee), the purchase of medicines, purchase biocas, and labor. The use of each indicator (input and output) are presented in Table 1.

Based on the results of the study the average number of cattle kept by farmers are four heads of cattle per household with a six month fattening period, so that in one year there are two period. In cattle, the use of coffee bran can give higher daily gain on fattening beef cattle than on beef cattle fed of forage only. In beef cattle fattening that use a coffee bran as a part of their fed, an average daily gain (ADG) $0.57 \mathrm{~kg} /$ head/day where as that on beef cattle that fed only a forage had an ADG $0.38 \mathrm{~kg} / \mathrm{head} /$ day. Beef cattle that fed coffee bran get sales result of Rp. 55,281,600 per year, while in beef cattle fed only a forage had a lower at Rp. 47.272 million. Supplementary feeding in the form of coffee bran causes difference in weight gain of livestock, it is supported by the results of a study by Sugama et al. (2009) and Suyasa et al. (2004) that reported that the supplementary feeding in the form of bran as much as $2 \mathrm{~kg} / \mathrm{head} /$ day in fattening beef cattle able to give an average growth of $625-650 \mathrm{~g} / \mathrm{head} / \mathrm{day}$ in three months of fattening period. The economic life of the cage is 10 years with the cost of $\mathrm{Rp} .3,000,000$ with a capacity of four 
heads, so the financial analysis performed starting from the making of investments to the tenth year. Method of calculation used in the financial analysis is cash flow method with a discount rate of $12 \%$ (according to the current study). Sales of manure every year with the selling price as shown in Table 2. The results of the financial analysis of cash flows in each treatment and the use of coffee bran (coffee waste) and without coffee bran, of fattening of beef cattle are presented in Table 2 and 3 were prepared from data farmers.

Table 1. Output and input of fattening cattle business

\begin{tabular}{lrr}
\hline \hline Source & Roughage + coffee bran & \multicolumn{1}{c}{ Roughage } \\
\hline Output & & \\
Cattle sales & $55,281,600$ & $47,272,000$ \\
Sales of manure & 514,800 & 686,400 \\
Total revenue & $55,796,400$ & $47,958,400$ \\
Input & & \\
Purchase of feeder cattle & $40,000,000$ & $40,000,000$ \\
Purchase of forage & $2,860,000$ & $2,860,000$ \\
Purchase of coffee bran & $1,075,200$ & 0 \\
Purchase of medicines & 100,000 & 15,000 \\
Purchase biocas (probiotic) & 100,000 & - \\
Reduction value of cages & 138,432 & 58,916 \\
Labor & 893,750 & 893,750 \\
Purchasing of cattle power servised & 90,000 & 90,000 \\
Total expenditure & $45,257,382$ & $43,917,666$ \\
Income & $10,539,018$ & $4,040,734$ \\
\hline
\end{tabular}

Table 2. Cash flow financial analysis fattening cattle with roughage + coffee bran

\begin{tabular}{cccccc}
\hline \hline Year & Income & Cost & Net income before DF & DF & Net income after DF \\
\hline 0 & 0.00 & $25,000,000$ & $(25,000,000)$ & 1.00 & $(25,000,000)$ \\
1 & $13,992,000$ & $25,257,382$ & $(11,265,382)$ & 0.89 & $(10,058,377)$ \\
2 & $55,796,400$ & $45,257,382$ & $10,539,018$ & 0.80 & $8,401,641$ \\
3 & $55,796,400$ & $45,257,382$ & $10,539,018$ & 0.71 & $7,501,465$ \\
4 & $55,796,400$ & $45,257,382$ & $10,539,018$ & 0.64 & $6,697,736$ \\
5 & $55,796,400$ & $45,257,382$ & $10,539,018$ & 0.57 & $5,980,122$ \\
6 & $55,796,400$ & $45,257,382$ & $10,539,018$ & 0.51 & $5,339,395$ \\
7 & $55,796,400$ & $45,257,382$ & $10,539,018$ & 0.45 & $4,767,317$ \\
8 & $55,796,400$ & $45,257,382$ & $10,539,018$ & 0.40 & $4,256,533$ \\
9 & $55,796,400$ & $45,257,382$ & $10,539,018$ & 0.36 & $3,800,476$ \\
10 & $55,796,400$ & $45,257,382$ & $10,539,018$ & 0.32 & $3,393,282$ \\
\hline
\end{tabular}

DF: Discount factor 
Tabel 3. Cash flow financial analysis fattening cattle with coffee bran

\begin{tabular}{cccccc}
\hline \hline Year & Income & Cost & Net income before DF & DF & Net income after DF \\
\hline 0 & 0.00 & $23,000,000$ & $(23,000,000)$ & 1.00 & $(23,000,000)$ \\
1 & $12,161,200$ & $23,917,666$ & $(11,756,466)$ & 0.89 & $(10,496,845)$ \\
2 & $47,615,200$ & $43,917,666$ & $3,697,534$ & 0.80 & $2,947,651$ \\
3 & $47,958,400$ & $43,917,666$ & $4,040,734$ & 0.71 & $2,876,115$ \\
4 & $47,958,400$ & $43,917,666$ & $4,040,734$ & 0.64 & $2,567,960$ \\
5 & $47,958,400$ & $43,917,666$ & $4,040,734$ & 0.57 & $2,292,821$ \\
6 & $47,958,400$ & $43,917,666$ & $4,040,734$ & 0.51 & $2,047,162$ \\
7 & $47,958,400$ & $43,917,666$ & $4,040,734$ & 0.45 & $1,827,823$ \\
8 & $47,958,400$ & $43,917,666$ & $4,040,734$ & 0.40 & $1,631,985$ \\
9 & $47,958,400$ & $43,917,666$ & $4,040,734$ & 0.36 & $1,457,129$ \\
10 & $47,958,400$ & $43,917,666$ & $4,040,734$ & 0.32 & $1,301,008$ \\
\hline
\end{tabular}

DF: Discount factor

Benefit cost ratio $(\mathrm{B} / \mathrm{C})$ obtained from fattening cattle production when it is added into the coffee bran ration with df $12 \%$ is of 2.62 means that for every expenditure on the present value of the rupiah will provide additional net income amounted to $\mathrm{Rp}$. 2,620 according to the current value. In accordance with the eligibility criteria, the activities of fattening cattle with added coffee bran is feasible to do because the $\mathrm{B} / \mathrm{C}>1$. On the development of the cattle business without coffee bran obtained by the $\mathrm{B} / \mathrm{C}$ of 1.04 , means that for every expenditure on the present value of the rupiah will provide additional net income of 104 rupiah according to the current value. In accordance with the eligibility criteria for the development of business activities bran cattle without coffee is not feasible to develop.

Based on the IRR which gained $21 \%$ IRR cattle development efforts with coffee bran and $1 \%$ in the cattle business development without bran coffee. With IRR of $21 \%$ indicates that the interest rate below $21 \%$, then the present value of net benefits (NPV) cattle business development efforts with bran coffee will not be zero. Or in other words that if farmers set "rate of return" average minimum acceptance of $12 \%$, then earned from these investments is greater than the minimum requirement. It concluded that, in terms of IRR, the cattle business development efforts with coffee bran feasible considering the internal rate of return is much greater activity than the commercial interest rate prevailing in the community. While in the cattle business development without coffee bran lower IRR of giving $1 \%$ bran coffee that these activities are not feasible to be developed, because the internal rate of this activity are smaller than commercial interest rates prevailing in the community. From the calculation of the three criterias used feasibility (NPV, IRR, and B/C ratio) on the development of the cattle business with coffee bran shows a positive result means that efforts on the development of cattle with coffee bran to develop.

Table 4. Investment criteria value financial feasibility cattle with and without coffee bran

\begin{tabular}{lcc}
\hline \hline Investmen criteria & With coffee bran & Without coffee bran \\
\hline B/C ratio & 2.62 & 1.04 \\
NPV (Rp) & $15,079,587.91$ & $-14,547,191.50$ \\
IRR $(\%)$ & 21 & 1 \\
\hline
\end{tabular}


From the analysis to include net income (year 0 up to $10^{\text {th }}$ ) to DF rate of $12 \%$ in fattening cattle with coffee bran obtained NPV of Rp. 15,079,587.91; IRR of $21 \%$ and B/C ratio of 2.62 (Table 4). As for fattening beef cattle without coffee bran (forage only) had negative NPV values obtained (Rp. 14,547,191.50); 1\% IRR and B/C ratio of 1.04 (Table 4). Means that the making of investments for cattle fattening business activities with the introduction of coffee bran will generate total net revenues during the ten year amounted to Rp. 15,079,587.91, while for the cattle development without coffee bran will earn a negative total net income (Rp. 14,547,191.50). It can be said that the beef cattle fattening when added bran coffee deserves to be developed considering the NPV is positive, whereas if only given a forage (without coffee bran) is not feasible to be introduced for the farmers because farmers will losses.

\section{Sensitivity analysis}

Analysis of sensitivity on the fattening beef cattle with coffee bran is required to see the extent of fattening cattle sensitivity to changes (deductions increase) and changes in product prices (increase-decrease) in the price of inputs that may occur, From the analysis that has been done in case of a decrease in output prices up to $5 \%$, while prices remained input obtained data showing that fattening cattle with coffee bran is still feasible. Generate NPV at $12 \%$ discount factor for $1,312,865.87$ with an IRR of $13 \%$ and B/C ratio of 1.89 . Meanwhile, when the fixed price output, while input prices rose to $5 \%$ Producing NPV at $12 \%$ discount factor Rp. 2,790,763.15 with an IRR of $14 \%$ and $\mathrm{B} / \mathrm{C}$ ratio of 1.96 and when both output and input rose 5\% will generate NPV of Rp. 16,557,485.19 with an IRR of $21 \%$ and $\mathrm{B} / \mathrm{C}$ ratio of 2.66.On the business development of cattle without coffee bran in the event of a decrease in production of up to 5\% although the prices fixed input livestock farming will be a loss, with a value of negative NVP (26,319,290.79), IRR negative (13\%) with $\mathrm{B} / \mathrm{C}$ of 0.42 or in other words a bit of a decline in output price and input price increases the farmer will lose money so it is not feasible.

\section{CONCLUSION}

Income received by farmers in the fattening of beef cattle in addition to coffee bran is higher than that without giving coffee bran. At the discount factor $12 \%$ in fattening beef cattle with coffee bran obtained NPV value greater than without giving coffee bran, so does the value of IRR coffee bran cattle given a higher value $(21 \%)$ than without coffee bran $(1 \%)$. Beef cattle when only relying on grass alone is very sensitive to change. A slight decline in output prices and input prices rise farmers would lose.

\section{REFERENCES}

Bali Provincial Livestock Office. 2009. Information data ranch Provincial Bali. Denpasar (Indonesia): Bali Provincial Livestock Office.

Budiari LG, Parwati IA. 2010. Optimization of waste utilization cattle farming in the village for supporting pots, Bangli Regency. In: National Seminar on Organic Agriculture Issues and Challenges. Ubud, 12 August 2010. Denpasar (Indonesia): BPTP Bali.

Gittinger JP. 1986. Analysis projects agricultural economics. Jakarta (Indonesia): UI Press.

Guntoro S, Yasa RM, Rubiyo, Suyasa IN. 2004. Optimizing goat farmer business integration with coffee plant. In: Proceedings of the National Seminar on Crop-Livestock Integration System. 
Denpasar (Indonesia): Livestock Research and Development Center in collaboration with the Institute for Agricultural Technology Bali.

Parwati IA, Suyasa IN, Budiari L. 2009. Giving waste plantation on cattle on crop-livestock integration in the Village Belanga. In: Prosiding National Seminar Appropriate Technology Agroindustrial and Dissemination of Results Lecturer Polinela. Lampung (Indonesia).

Suyasa IN, Soethama IKW, Guntoro S. 2004 Productivity farming wetland in approach systems integration crop-livestock in Subak Rejasa, Tabanan, Bali. In: Proceedings of the National Seminar on Crop-Livestock Integration System. Denpasar (Indonesia): Livestock Research and Development Center in collaboration with the Institute for Agricultural Technology Bali.

Sugama N, Londra IM, Sutami P.2009. Effect of probiotics on growth bio-cas given Bali cattle feed the grass and waste vegetable. In: National Seminar for Farmers Innovation and Competitiveness Improvement of Agricultural Products. Malang (Indonesia): BPTP Jawa Timur.

Tisna IM. 2002. Land reforms in the context of regional development of the Province of Bali. In: Optimization of Soil and Water Resources Utilization. Available for Sustainability Development, Agriculture Particular Sector. Denpasar (Indonesia): Fakultas Pertanaian Universitas Udayana.

Zaenuddin D, Kompiang IP, Hamid H. 1995. Waste utilization coffee in rooster rations. Set of research results. TA 94/95 state budget. Bogor (Indonesia): Livestock Research InstituteCiawi. 